\title{
The Interorganizational Challenge of Agricultural Reform in Bosnia and Herzegovina
}

Eric Martin, Brian Fahey *

Abstract:

The case study reported below examines USAID's "Linking Agricultural Markets with Producers" program. This program complemented Bosnia and Herzegovina's overall sustainable agriculture policies. Implementing organizations quickly recognized that sustainability must be achieved not only from an environmental perspective, but in the interorganizational domain as well. Public, private and nonprofit players had to develop the social, economic and political infrastructure required for sustainable agricultural projects to succeed. These institutional changes were at times more difficult than the sustainable agriculture policies and practices they supported. Framed within LAMP's identification of constraints and proposed solutions for agricultural reform, we explored the interorganizational linkages required for success. We identified three distinct types: 1) those within the international community, 2) those within the local community and 3) those between international and local organizations. The case illustrates the institutional and managerial obstacles to and opportunities for implementing sustainable development reforms in transition settings.

Keywords: international development assistance, interorganizational cooperation, agriculture

JEL: F53

DOI: $10.2478 / v 10033-009-0010-7$

\section{Introduction}

The Linking Agricultural Markets with Producers (LAMP) project served as one component of the United States Agency for International Development's (USAID) comprehensive strategy for sustainable economic development in Bosnia and Herzegovina (BiH) in early 2000. LAMP business consultants were charged to work with local agricultural producers, distributors and retailers to develop stronger market linkages throughout the value chain to enhance the maturation and sustainability of the sector.

According to USAID's Sustainable Agriculture Policy, its programs target efforts that are "ecologically sound, economically viable and socially responsible." ${ }^{\text {s }}$ Such efforts require sound environmental and natural resource management, but, according to the policy statement, only succeed when coupled with sound economic policy

\footnotetext{
${ }^{1}$ http://www.usaid.gov/our_work/agriculture/sustainable_ag.htm
}

and good governance. Efforts to implement sustainable agricultural best practices in $\mathrm{BiH}$ required action far beyond the relatively simple transfer of knowledge and provision of resources.

Development organization representatives and their contractors often served as brokers that maintained, fostered and built relationships throughout the sector to enhance the promise of sustainability in terms of both land use and business development. Three distinct linkage types influenced the successful implementation of their work.
Eric Martin
Eastern Connecticut State University
Department of Business Administration
E-mail: MartinE@EasternCT.edu 
- Interorganizational relationships (IORs) existed between international and local players. This relationship between international development assistance organizations and their local counterparts often received the most attention in literature specifically targeting the transfer of assistance from international to host country players.

- IORs existed between USAID, their contractors and other bi- and multi-lateral players, such as the World Bank, the International Monetary Fund, a myriad of NGOs, and the Office of the High Representative $(\mathrm{OHR}$; the UN protectorate government in Bosnia and Herzegovina). These relationships required a different set of competencies and took a different 'tone' than those between international and host as they required a more political, competitive, and occasionally hostile give and take. It was often unclear who the lead agency indeed was, or whose approach would be most effective. As such, the negotiation of social order proved more visible than that between international and local - where the power balance was more obvious.

- IORs existed among local private, nonprofit and governmental organizations (ministries and agencies) at the federal, entity, canton and municipal levels ${ }^{2}$ within the agricultural sector, and beyond (banking, regulatory, transport, etc). These relationships were typically beyond the control of development assistance organizations, though represented the ultimate goal of such development assistance. Strong, functional, cross-sectoral local relationships were required for sustainability in the agricultural sector.

While USAID contracted agencies to transfer funds, resources and expertise through the first IOR vehicle, from international to local, contractors found the success of their programs hinged upon successful relationships across all three types, though performance measurements and indicators of success typically only stressed the first - the actual flow of assistance dollars and technical knowledge. The auxiliary activities that supported such flows were rarely measured.

Employing an overtly interorganizational perspective might help donors and contractors (principals and agents) better understand the auxiliary actions required for programmatic success - in terms of means and processes, not just end results and tangible deliverables. If strong, international and cross-sectoral relationships are required for sustainability, and IOR perspective seems

\footnotetext{
2 The Dayton Peace Accords compromises resulted in one (rather weak) national government, two entity level government, the Republika Srpska and the (Muslim-Croat) Federation. The Federation entity was further divided into cantons.
}

appropriate to measure performance. Such a perspective might improve contracts and agency problems between USAID and its contractors. And this IOR approach can address some classic development questions about local ownership, dependency, conditionality and patronage in a more pragmatic fashion.

\section{Research goals and objectives}

Below, we describe the LAMP case in Bosnia and Herzegovina, considered by all respondents as a fairly typical, non-controversial ${ }^{3}$ USAID sustainable agriculture project in a transition setting, with a focus not only on the technical agricultural best practices, but the institutional environment required for success as well. First we provide an overview of the methods used. We then frame the paper with a review of the management literature on both development assistance and IORs more broadly, addressing the various levels critical to IOR analysis.

The LAMP project team identified five needs in the agricultural sector and designed a four-pronged plan to address those needs. We examine the interorganizational dynamics of both 1) the constraints to success and 2) the proposed solutions. By doing this, we exposed three qualitatively distinct types of IORs: Between international and local players, among international players and among local players. We then discuss the implications for program success at various levels, across the three different types of partnerships, identifying opportunities and obstacles for change in each of the three IOR types. We conclude with thoughts regarding the role of IORs in development settings.

\section{Methods and materials}

The work is based on interviews with development professionals working for and with LAMP and other players in the agricultural sector, as well as site visits to agricultural businesses and LAMP clients throughout Bosnia and Herzegovina. Interviews took place in Mostar, Sarajevo, and rural communities throughout $\mathrm{BiH}$, in 2005. The analysis reported here (a subset of a larger research agenda ${ }^{4}$ ) relies specifically on 17 interviews with

\footnotetext{
${ }^{3}$ We mention this as many programs in $\mathrm{BiH}$ are significantly hampered by difficult ethnic tensions. Apparently, this is not one of them.

${ }^{4}$ These data were additionally informed by over 150 interviews with development professionals in the field, secured through annual field visits to Bosnia and Herzegovina since 1999 that help frame the authors thinking in terms of Bosnia and Herzegovina's overall development objectives. These interviews provided insight into the broader context within which LAMP activities take place. In addition, the second author directed the LAMP project after over a decade of international development experience and helped write the project's work plan from which the project description in this manuscript draws heavily.
} 
representatives of LAMP, as well as LAMP partner and client organizations. Interviews typically lasted 1-2 hours. Several key individuals were interviewed multiple times.

The long interview format was used (Lofland and Lofland 1995; McCracken 1988; Spradley 1979; Strauss and Corbin 1990). Interviews began with personal backgrounds, overviews of organizational activities and 'grand tour' questions such as, 'Can you tell me about the political landscape in agricultural?' More specific questions followed, as did some crosschecking based on information from previous interviews, such as 'I understand there could be a conflict between your approach and others, how should I view that?'

Official documents were obtained directly from organizations via e-mail or websites. Meeting agendas and minutes, project proposals, and reports were collected during field research. Some respondents provided us with unofficial reports, internal white papers and e-mail exchanges between key players. We also attended agriculture-related conferences and meetings as both participant and observer.

Interviews, observations (recorded through journaling and notes from conferences and meetings) and documents were coded to enhance subsequent interviews and shape new lines of questioning (Lofland and Lofland, 1995; Strauss and Corbin, 1990). Those codes, over several iterations, formed the basis of the framework used to present this paper. Codes revolved around several key concepts including; 1) constraints to success, 2) proposed solutions, 3) levels of analysis, 4) type of interorganizational relationship and 5) various classic development concerns or dilemmas.

\section{Literature review}

We employed two primary streams of literature. The first targeted development assistance. The second addressed interorganizational relationships. Together, they framed our analysis of the constraints to change LAMP encountered.

We suggest the interorganizational perspective effectively captures the essence of development assistance because of its "meso" level - its position between the high-level political, diplomatic and policyrelated dialogues and the more action oriented groundlevel results orientated contractors and implementing partners. Development professionals in Bosnia and Herzegovina and throughout the Balkans repeatedly suggested that it was this meso or interorganizational level that constantly surfaced as the primary determining factor regarding the success or failure of reform efforts.

\subsection{Development Assistance}

Development scholars have grappled with the often paradoxical role of the international community in reform and development (Black, 1999; Leeson and Minogue, 1988; Mosse, Farrington and Rew, 1998; Tisch and Wallace, 1994). Dependency theory highlighted the negative influence of the global system on underdeveloped nations (Randall and Theobald, 1998), while modernization theory targeted host country patronage systems, inability and lack of incentives (Todaro, 1994). No single paradigm dominates the field (Sklar, 1987, 1995; Brinkerhoff, 2004). Brinkerhoff and Goldsmith (2004) suggested development is an attitude as opposed to any specific model. Different perceptions of development assistance by different actors in the process influence reform, as practitioners debate the use of various intervention methods, the role of local players, the sequencing of reforms, the use of conditionalities attached to loans, and the ways to promote conditions that would enable reforms to flourish.

In Bosnia and Herzegovina, the international community, primarily through the Office of the High Representative (OHR), the UN quasi protectorate government, imposed reforms and removed obstructionist, though elected, local officials. These actions stripped power from controlling elites who were expected to be active partners in implementing the changes, creating tensions between developers and obstructionists. However, the international community could not succeed in any reforms without local support.

Although development scholars largely abandoned dependency theory in the 1980s (Randall and Theobald, 1998; Sklar, 1995), its logic proved intriguing with respect to development assistance in Bosnia and Herzegovina, and especially the $\mathrm{OHR}$, that might perpetuate groundlevel dependency by creating a "moral hazard problem adversely affecting the aid recipients' incentives to undertake structural reform" (Svensson, 1997: 2).

In addition to the paradox inherent in a dependency or modernization approach or perspective, the flow from policy to implementation over time in development work takes place at many levels - both within the international community, within the local host community and between internationals and hosts. Scholars and practitioners have employed public administration, management and organizational research to analyze, understand and improve the transfer of resources and technologies from donor to recipient (Aubrey, 1997; Black, 1999; Brinkerhoff, 1996; Evans, 1996a; 1996b; Griffin, 2000; Hardy and Phillips, 1998; Kiggundu, 1996; Mosse, Farrington and Rew, 1998; Ostrom, 1996; Riggs, 1960; Rondinelli, 1987, 1994; Westley and Vrendenburg, 1997). 
Scholars have discussed the value of coordinating policies and activities within the international community (Black, 1999), incorporating strategic management perspectives to capture "the big picture" of development (Goldsmith, 1996). Others have profiled developing country organizations and their environment, reconceptualizing development as a complex set of IORs to interpret policy outputs and implementation, (Aubrey, 1997; Kiggundo, 1996; Njoh, 1993).

Development scholars have also addressed interdependencies between tasks and players, both local and international, through cases studies. Boyce (1995) exposed the relationship between political stabilization and macroeconomic reform in El Salvador. Haughton (1998) stressed that to reconstruct Congo's war-torn economy, political, social and economic issues had to be addressed

simultaneously. Evans (1996a, 1996b) and Ostrom (1996) discussed synergy in development and the importance of convergence between different strains of activity.

Some work specifically examines Bosnia and Herzegovina with the same interorganizational

lens. Hasic (2006) exposed the complexity of the international

community, stressing the conflict and lack of coordination that existed despite the interrelatedness of tasks and organizational mandates. Martin and Miller (2003) targeted interorganizational cooperation within the NGO community and Martin (2004) addressed the same in the area of privatization in BiH. Pech (2000) and Shuey (2003) examined the media sector. All of these studies referred to the complex interorganizational arrangements required in Bosnia and Herzegovina in the years after the war, where post-conflict activities, reconstruction, economic and political transition programs, and general development activities were all taking place simultaneously.

The development research discussed above implicitly suggests that three distinct types of IORs exist in development settings and different opportunities and obstacles to success can be found in each. IORs exist between international organizations and local players, with the power balance and flow of information, funds, and resources putting the internationals in the dominant position. IORs also exist between public, private and nonprofit sector international organizations (i.e. the International Community). And finally, IORs exist among local, in this case $\mathrm{BiH}$, organizations. These organizations must ultimately cooperate, coordinate and collaborate for any international efforts to take hold over time. Figure 1 tries to convey the myriad relationships that existed in this setting, each dominated by different issues, yet nearly all players worked with nearly all the other types of organization. 


\subsection{Interorganizational Relationships}

IORs emerge as strategic responses to a variety of factors. Several of these key concerns are addressed below, according to the various levels of analysis where they are likely to emerge, as identified by Hannan and Freeman (1977) and effectively used by Fombrun (1986) to address structural dynamics within and between organizations.

Environmental level. Organizational environmental conditions can be categorized as (1) placid and random, (2) placid and cluttered, (3) disturbed and random, or (4) turbulent (Emery and Trist, 1965; Terreberry, 1968). Actual physical or geographic proximity also have emerged as key variables (Gray, 1985; Schermerhorn, 1975). Benson (1975) extended this line of thinking by conceptualizing interorganizational relationships as political economy. Six aspects of the environment potentially influence whether an IOR might emerge, including resource concentration or dispersion, power concentration or dispersion, network autonomy or dependence, environmental dominance patterns, resource abundance or scarcity, and control mechanisms (Barr, 1998; Clark, 1965; Dickson and Weaver, 1997; Evans and Klemm, 1980; Human and Provan, 2000; Kochan, 1975; Kraatz, 1998; Lammers, 1988; Levine and White, 1961; Meyer, 1982; Provan and Milward, 1995; Ruef and Scott, 1998; Westphal, Gulati and Shortell, 1997).

Population and community levels. The extent of domain consensus (Schermerhorn, 1975), predispositions to cooperate (McCaffrey, Faerman and Hart, 1995) and legitimacy of the industry locally and in its organizational field (Human and Provan, 2000) prove critical to IORs. Research targeting the influence of prior alliances on repeated ties are important (Gulati, 1995a,b; Gulati and Gargiulo, 1999; Parkhe, 1993). Empirical studies of the pre-existing structural dynamics regarding both strong and weak organizational ties (Granovetter, 1973), network position (Rice and Aydin, 1991), organizational similarities (Larsson and Finkelstein, 1999), fit (Molnar, 1978), shifts in bargaining power (Inkpen and Beamish, 1997), and integration, control and stability (Provan and Milward, 1995), within the organizational domain, community or population, allow greater understanding of the changes that a domain might experience as alliances develop.

Organizational level. Organizational goals and norms provide opportunities or obstacles to interorganizational linkages (Schermerhorn, 1975). Boundary permeability reflects the extent to which organizations encourage, prevent or limit external ties. Organizational complexity, formalization, centralization, size and structure prove important potential indicators of IORs (Burns and Wholey, 1993). Firms involved in complex tasks may seek assistance from specialized partners (Powell, Koput and
Smith-Doerr, 1996). Multi-divisional organizations or firms may find it easier to form IORs by delegating authority to departments or divisions that might have experiences with interdepartmental ties (Ghoshal and Bartlett, 1990). Additional organizational variables include strategic flexibility (Young-Ybarra and Wiersama, 1999), differences across organizational levels (Klongan et al., 1976; Turk, 1970), absorptive capacity (Koza and Lewin, 1999; Shenker and Li, 1999), and levels of or capacity for trust (Zaheer, McEvily and Perrone, 1998). Some organizations may or may not have the capabilities, staff, resources or inclination to enter into alliances (Miner, Amburgey and Stearns, 1990; Weber, 1995). Such intra-organizational analysis might be useful to determine some of the potentially enabling characteristics long before IOR formation.

Group and individual levels. Individuals initiate IOR development based upon perceptions of organizational resource scarcity, value expectancy, and coercive pressure (Schermerhorn, 1975). These individuals carry with them various predispositions that indicate the extent to which participants look favorably on cooperative ventures as a feasible strategy at all (McCaffrey, Faerman and Hart, 1995), irrespective of specific needs. Also, much information often is already known about potential partners. In order to enter into an $\mathrm{IOR}$, or realize personal or organizational needs for establishing an IOR, individual participants must be aware of the activities of other organizations, to know with whom to potentially partner (Van de Ven, 1976). This information is gained, in part, through individual level ties, both strong and weak (Granovetter, 1973), individual perceptions and knowledge (Dickson and Weaver, 1997) and individual roles (Ibarra, 1993a, 1993b). Social network analyses (Carrol and Teo, 1996; Gulati and Westphal, 1999; Ibarra, 1993a,b; Tichy, Tushman and Fombrun, 1979) and Putnam's (2000) work on social capital revealed the importance of personal ties. Perceptions of trust, reputation and legitimacy of other individuals and other potential partner organizations (Larson, 1992; Ostrom, 1998) can be established long before organizations enter into alliances.

\section{Constraints to agriculture reform ${ }^{5}$}

\subsection{The Agriculture Cluster in Bosnia and Herzegovina}

Michael Porter's (2002) notion of cluster competitiveness helped provide an overview to the

\footnotetext{
${ }^{5}$ This section relies on the LAMP Work Plan, revised December 2003; Rural and Agricultural Incomes with a Sustainable Environment (RAISE) written by the second author for Associates for Rural Development, Burlington, Vermont.
} 


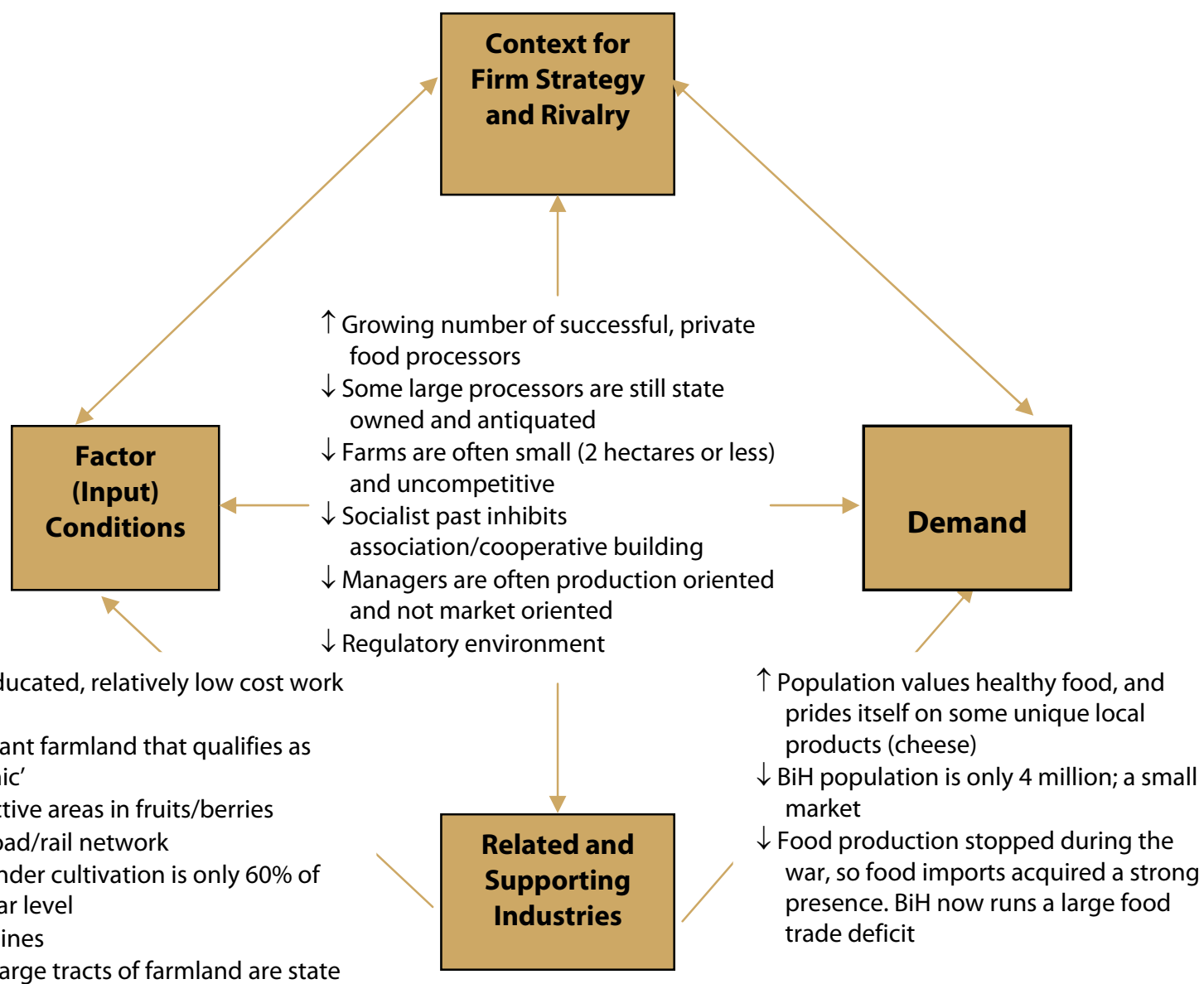

$\uparrow$ Well educated, relatively low cost work force

$\uparrow$ Abundant farmland that qualifies as 'organic'

$\uparrow$ Productive areas in fruits/berries

$\downarrow$ Poor road/rail network

$\downarrow$ Area under cultivation is only $60 \%$ of pre-war level

$\downarrow$ Landmines

$\downarrow$ Some large tracts of farmland are state owned. and unused

$\uparrow$ Banking sector is stable (but limited flexibility for Ag lending); USAID DCA financing

$\downarrow$ No state level agricultural ministry or certification body, which restricts exports

$\downarrow$ Some links between university and industry, but generally weak

Figure 2 demonstrates that the economic environment for the BiH agriculture sector faces significant obstacles, which impede its ability to compete.

agricultural sector (see Figure 2). Clusters improve competitiveness by enhancing efficiency through competition, increasing innovation and stimulating new business formation that serves to expand the cluster. The $\mathrm{BiH}$ agricultural cluster had tremendous potential, but elements of the cluster stifled growth. Although the international community influenced and assisted agricultural reforms, change ultimately relied upon locals. However, action had to take place at multiple levels simultaneously to enact change. As Porter (2002) suggested, "Wealth is actually created in the microeconomic level of the economy, rooted in the sophistication of company strategies and operating practices as well as in the quality of the microeconomic business environment in which a nation's firms compete. Unless there is appropriate improvement at the microeconomic level, macroeconomic, political, legal, and social reforms will not bear full fruit." The key to enhancing cluster competitiveness is to identify the change makers, and bring them to the table so they can create synergies and overcome the following constraints at multiple levels from policy to implementation.

Below, we first address the constraints to growth and change in the agriculture sector, followed by LAMP's programmatic components designed to address those constraints.

Constraint \#1: The Institutional Environment: The Dayton Peace Accords left in place a complex institutional environment based on difficult compromises that were necessary to reach agreement, but no longer effectively serve the country. Major questions existed in areas where legislation was non-existent, inadequate or controversial 
since responsibilities overlap multiple agencies. For example, unclear and uneven enforcement of land management laws made it difficult for local producers to use potentially productive farm land. Banking laws prohibited cooperatives from making loans. And microcredit organizations could make loans, but could not raise operating capital from the savings. Furthermore, they were limited by law to loans of three years or less; inappropriate for the agricultural sector. Additionally, $\mathrm{BiH}$ lacked a State Ministry of Agriculture. And the entity level Ministries of Agriculture were overextended with political and administrative problems. Their ineffectiveness left donors and potential investors fearful of an environment marked by confusing and inconsistent legislation at various levels of government, a lack of transparency, corruption, porous borders and a large shadow economy.

Constraint \#2: Market Linkages: According to LAMP research, processors faced shortages of domestic products to process, while domestic farmers indicated that they were unable to locate markets for their products. This apparent paradox reflected the immaturity of the sector, the dearth of market information, the influence of imported products and the overall lack of organization in the sector. A key concern was that processors preferred large quantities and thus had trouble working with the many small producers. And those producers did not organize themselves well enough to consistently provide large quantities collectively.

Constraint \#3: Inefficient Production: Agricultural production in $\mathrm{BiH}$ was below potential and yields were estimated at approximately half of western European levels. Land and labor productivity has not returned to pre-war levels. Less than optimal machinery utilization, low input use, and unimproved seed varieties further reduced efficiency within the producer sector. Imported inputs were also expensive. These factors translated into higher production costs than in other countries.

From the farm gate, high per unit costs derived from the need to aggregate small quantities, inadequate handling facilities leading to high spoilage or losses and processing companies utilizing only low levels of installed capacity. Other high operating costs and margins or taxes further reduce agricultural competitiveness. Management systems are poor and producer groups (associations, cooperatives and partnerships) are limited in size and scope. Poor and outdated seed varieties, technical packages inappropriate for small-scale producers, and outdated farming methods and machinery all hampered the sector.

Constraint \#4: Land Ownership: Small, fragmented farms dominated $\mathrm{BiH}$ agriculture. Approximately 90 percent of the agricultural land in $\mathrm{BiH}$ was owned by individual farmers in multiple plots totaling 2-5 hectares.
For many crops, these small farms contributed to low productivity and limited the ability of the farmer to adopt modern management systems. Pre-war efforts at land consolidation to reduce land fragmentation and the provision of support for farm cooperatives had limited impact. Land sales were also subject to a 6 percent sales tax, leading to inheritance (with no sales tax to immediate relatives) rather than sales to transfer ownership. Over generations, this resulted in land fragmentation as land was divided among beneficiaries. Furthermore, farm land was often not registered in the current owner's name. This was not a concern under the Yugoslav economy, where bank credit to small farmers was often not dependent on land collateral, as is the requirement by most banks today. Additionally, re-registering land was a lengthy, bureaucratic process. There were also legal fees involved in re-registration, which was an impediment for poor farmers to promptly re-register their land. Another problem with land ownership was leasing. Some of the most productive and larger tracks of land were state owned. The regulations to lease land were sometimes unclear or politically influenced. There were cases where state owned farm land had been leased to political friends for periods of 20 years at prices significantly lower than market value. Finally, pre-war urban migration and the more widespread war-induced migration, land mines and uneven resettlement resulted in high levels of unused agricultural land. Some leasing and land sales transactions occurred. However, in general the market for land did not function very well and land was not widely accepted as collateral for loans.

Constraint \#5: Rural Credit: Demand for rural credit exceeded supply. Resources remained limited as the micro financing organizations had not effectively tapped into domestic credit sources. Commercial banks were typically unwilling to provide agricultural producer credit. High interest rates and poor terms constrained most potential borrowers, though over time, rates fell and longer-term loans became available. High collateral requirements remained a problem. The government was considering an interest rate subsidization program for agricultural loans although budget and other constraints may prevent this from being implemented. Since 1999, several foreign banks opened branches in FBH and became dominant in the markets for deposits and consumer loans. In the RS, development of the private banking sector proceeded more slowly. Several FBH banks were liquid but the number of viable commercial loan applications being received was limited.

The five constraints are summarized in Table 1. 


\begin{tabular}{|c|c|c|c|c|c|}
\hline & $\begin{array}{l}\text { Institutional } \\
\text { Environment }\end{array}$ & $\begin{array}{c}\text { Market } \\
\text { Linkages }\end{array}$ & Inefficient Production & $\begin{array}{c}\text { Land } \\
\text { Ownership }\end{array}$ & $\begin{array}{l}\text { Rural } \\
\text { Credit }\end{array}$ \\
\hline $\begin{array}{c}\text { Environmental } \\
\text { Level }\end{array}$ & $\begin{array}{l}\text { - Dayton Peace } \\
\text { Accords } \\
\text { - Land / Owner } \\
\text { Laws } \\
\text { - Credit / Lend Laws } \\
\text { - Government } \\
\text { Transparency }\end{array}$ & & & $\begin{array}{l}\text { - Dayton Peace } \\
\text { Accords } \\
\text { - Land / Owner } \\
\text { Laws } \\
\text { - Leasing Laws } \\
\text { - Land Registration } \\
\text { - Urban Migration }\end{array}$ & $\begin{array}{l}\text { - Credit / Lend } \\
\text { Laws }\end{array}$ \\
\hline $\begin{array}{c}\text { Population \& } \\
\text { Community } \\
\text { Level }\end{array}$ & & $\begin{array}{l}\text { - Market Data } \\
\text { - Small Producers } \\
\text { Undesirable } \\
\text { - Ineffective } \\
\text { Cooperatives }\end{array}$ & $\begin{array}{l}\text { - General Land and } \\
\text { Labor Productivity } \\
\text { - Operating Costs } \\
\text { - Inadequate Handling } \\
\text { Facilities } \\
\text { - Processing Firms not } \\
\text { at Capacity } \\
\text { - Limited Producer } \\
\text { Groups }\end{array}$ & $\begin{array}{l}\text { - Poorly Developed } \\
\text { Real Estate Market }\end{array}$ & $\begin{array}{l}\text { - Very High } \\
\text { Interest Rates } \\
\text { - Poor Terms } \\
\text { - High } \\
\text { Collateral } \\
\text { Requirements } \\
\text { - Short Terms }\end{array}$ \\
\hline $\begin{array}{c}\text { Organizational } \\
\text { Level }\end{array}$ & & & $\begin{array}{l}\text { - Minimal } \\
\text { Mechanization } \\
\text { - Poor Management } \\
\text { Systems } \\
\text { - Outdated Seed } \\
\text { Varieties }\end{array}$ & & $\begin{array}{l}\text { Willingness to } \\
\text { risk, } \\
\text { - Lack of } \\
\text { Collateral }\end{array}$ \\
\hline $\begin{array}{l}\text { Group \& } \\
\text { Individual } \\
\text { Level }\end{array}$ & & $\begin{array}{l}\text { - Time pressures } \\
\text { - Transportation \& } \\
\text { Communication }\end{array}$ & $\begin{array}{l}\text { - Lack of Management } \\
\text { Skills } \\
\text { - Lack of Technical skills }\end{array}$ & $\begin{array}{l}\text { - Difficulty navigating } \\
\text { bureaucracy } \\
\text { - Frustration }\end{array}$ & $\begin{array}{l}\text { - Risk aversion, } \\
\text { - Lack of } \\
\text { Collateral }\end{array}$ \\
\hline
\end{tabular}

Table 1: Constraints

\section{LAMP project model ${ }^{6}$}

LAMP's goal was to increase the rate of economic growth in Bosnia and Herzegovina through expanded, environmentally sustainable production and sales of value-added agricultural products. By strengthening linkages among producers, processors and their markets, the project enabled agribusiness enterprises to locate and meet domestic and export market demand.

The development and/or strengthening of market linkages among producers, traders, processors and wholesale or retail enterprises was achieved through support and assistance of various kinds at several levels. SMEs, including cooperatives and associations, were provided technical assistance and small grants to enable them to serve as the aggregators and producer counterparts to traders, processors and wholesale/retail personnel. Processing, wholesale, retail and exporting

\footnotetext{
${ }^{6}$ LAMP was a three-year USAID funded project awarded to Associates in Rural Development (ARD) in 2003 as part of a RAISE IQC (PCE-I-00-9900001-00, order no. 822), for $\$ 22.6$ million. ARD subcontracted with Land O'Lakes and other subcontractors.
}

enterprises were assisted in establishing better information systems and methods of connecting to producer/suppliers and final markets. Many elements of the marketing chain gained better access to credit sources and supplies of credit were increased. And supportive policy and regulatory changes were developed. The LAMP project's four key components are discussed in more depth below.

Component \#1 - Market Chain Development: A key constraint was the lack of sales and marketing skills, limited customer or market orientations and a lack of management skills among both producers and processors. Many market chain participants found it difficult to connect to local and regional markets. While the inability to conduct sales within the regional markets was partly due to the lack of functioning state-level certification bodies, it was also due to the limited skills in identifying and penetrating markets and completing transactions. LAMP worked to train, advise and consult with farmers and food processors to address these needs.

Small economies of scale due to small farm size also lead to higher costs and lower profits. And the poor perception of agriculture as an engine of growth limited potential investment. LAMP addressed this by making local agricultural companies more profitable, and actively 
promoting their successes to reverse the sector's poor reputation. As $\mathrm{BiH}$ consumers saw agriculture as a more profitable activity and more frequently purchased high quality domestic food, it might generate interest in the sector. The small size of firms in $\mathrm{BiH}$ was addressed through the formation of partnerships, associations and cooperatives designed to enhance buying or selling power. Association meetings were a great avenue to introduce buyers and sellers. LAMP also linked buyers and sellers by inviting expert speakers on critical topics, disseminating more and better market information, including prices, volumes, quality, location, contacts, etc. Additional linkages included an agricultural business directory, web site(s), and trainings for associations to do such activities themselves.

Finally, most nations in the region established statelevel institutions that regulated and monitored food quality, plant health and veterinary standards. Often these standards were in accordance with EU requirements, thus enabling producers and food processors to export to the EU. However, in Bosnia and Herzegovina there was a lack of these necessary institutions at the state-level, thus resulting in the exclusion of many $\mathrm{BiH}$ food items for export to the EU. LAMP worked with relevant $\mathrm{BiH}$ government institutions to build the capacity to become a respected exporter of products meeting regional or EU standards.

\section{Component \#2 - Strengthening Market} Integrators: Market Integrators (Ml's) provided inputs and/or services within the agricultural value chain and fall into two groups. The first included dealers, transportation providers, storage providers, consulting firms, marketing outlets and buying agents. The second included organizations that combined small producers around a common interest or need, such as producer associations and cooperatives. Many such associations and cooperatives were active in the socialist economy, although they were largely dependent on the state for funding and direction, and not accountable to the member companies or producers. In recent years independent, member-driven associations and cooperatives emerged, but they were challenged to be sustainable. Often they lacked expertise in strategic management, marketing and finance, therefore limiting their effectiveness.

Many opportunities existed to provide technical assistance to increase and improve product standardization and quality, increase the available domestic raw material base, reduce imports and create jobs. Interventions included trainings, technical assistance, assisting in the strengthening and creation of producer associations and cooperatives, facilitating the establishment of long term relationships between Mls and producer organizations. LAMP did face challenges in these activities, such as finding $\mathrm{MI}^{\prime}$ s eligible for interventions, developing local staff and consulting capacity that could provide training and technical assistance in the future, addressing policy issues that were impediments to agricultural development, developing eligibility criteria for small grants to producer organizations, and encouraging banks and MFI's to work with LAMP clients who apply for loans.

Component \#3 - Access to Credit: Individual family farmers were consistently blocked in their access to credit from commercial banks because they were not registered businesses, and typically did not have historical records of sales, expenses and productivity. On the other hand cooperatives, market integrators and food processors that may have had access to loans from commercial banks, usually could not take on loans with such high interest rates under short terms.

A fundamental restraint on the availability of credit was a lack of experience and expertise in agricultural lending throughout the $\mathrm{BiH}$ financial system. It appeared that some MFI's and banks had not developed models for assessing or managing this form of risk. In turn, they did not have staff trained to lend to agricultural producers, groups of producers, cooperatives, market integrators or food processors. Through one-on-one assistance, provided by LAMP credit specialists, banks and MFI's became better acquainted with due diligence for agricultural lending. LAMP worked primarily with four micro-finance institutions (MFI's) and three commercial banks to improve access to credit. Pre-screened MFI's were eligible for grants that help alleviate liquidity pressures - a major constraint. In cooperation with the USAID/FSBAT Project, businesses were encouraged to work with institutions participating in the Development Credit Authority (DCA) mechanism administered by FSBAT. Essentially, this was a fund that guaranteed up to $\$ 31$ million by providing a $50 \%$ guarantee to the bank in the event of a loan default. Screening guidelines were created to select business loan projects with good potential for success. These activities were facilitated using a highly-trained staff of Finance Specialists hired from the recently concluded USAID Business Finance Project.

Component \#4 - Policy and Regulatory Development: The policy component may have been the most challenging aspect of the LAMP project, but success in this component had the potential to produce the most dramatic results. The issues that negatively impacted the agricultural sector were generally well known and documented by local officials. Yet, despite clear analyses and recommendations, the pace of agricultural policy reform remained slow. Certainly the continually shifting political landscape in Bosnia and Herzegovina contributed to the slow pace. 


\begin{tabular}{|c|c|c|c|c|}
\hline & $\begin{array}{l}\text { Market Chain } \\
\text { Development }\end{array}$ & $\begin{array}{l}\text { Strengthening Market } \\
\text { Integrators }\end{array}$ & Access to Credit & $\begin{array}{l}\text { Policy and Regulatory } \\
\text { Development }\end{array}$ \\
\hline \multicolumn{5}{|l|}{$\begin{array}{l}\text { Environmental } \\
\text { Level }\end{array}$} \\
\hline $\begin{array}{l}\text { Population \& } \\
\text { Community } \\
\text { Level }\end{array}$ & $\begin{array}{l}\text { - Associations and } \\
\text { Cooperatives, to reach } \\
\text { economies of scale } \\
\text { - member lists, contact } \\
\text { numbers } \\
\text { - Business directory, websites }\end{array}$ & $\begin{array}{l}\text { - Linking dealers, } \\
\text { transportation } \\
\text { providers, storage } \\
\text { providers, consulting } \\
\text { firms, marketing } \\
\text { outlets and buying } \\
\text { agents }\end{array}$ & & $\begin{array}{l}\text { - Become acquainted } \\
\text { with donors, learn the } \\
\text { issues, work with } \\
\text { government officials, } \\
\text { and private sector } \\
\text { - advocate for local } \\
\text { regional cooperative } \\
\text { policies } \\
\text { - lobby, work with } \\
\text { associations }\end{array}$ \\
\hline $\begin{array}{l}\text { Organizational } \\
\text { Level }\end{array}$ & $\begin{array}{l}\text { - Provide Market } \\
\text { information, data, prices, } \\
\text { volume, quality, location, etc. }\end{array}$ & & $\begin{array}{l}\text { - Registering businesses } \\
\text { - importance of historical } \\
\text { record of sales, expenses, } \\
\text { productivity, taxes, }\end{array}$ & \\
\hline $\begin{array}{l}\text { Group \& } \\
\text { Individual } \\
\text { Level }\end{array}$ & $\begin{array}{l}\text { - Improving Sales and } \\
\text { Marketing Skills } \\
\text { - Train, Advise, Consult with } \\
\text { Local farmers and food } \\
\text { processors } \\
\text { - Expert Speakers, field trips, } \\
\text { to link individual players } \\
\text { - EU Food Policy regulations } \\
\text { (learn, adapt) }\end{array}$ & $\begin{array}{l}\text { - Training in Strategic } \\
\text { Management, } \\
\text { Marketing and Finance } \\
\text { - Developing local } \\
\text { consulting capacity }\end{array}$ & $\begin{array}{l}\text { - Training lending agent } \\
\text { staff to work with farmers } \\
\text { and agricultural players } \\
\text { - Provide consulting and } \\
\text { workshops for } \\
\text { agricultural due } \\
\text { diligence }\end{array}$ & $\begin{array}{l}\text { - Identify specific } \\
\text { individual Change } \\
\text { Agents } \\
\text { - workshops for players } \\
\text { on lobbying, } \\
\text { influencing policy }\end{array}$ \\
\hline
\end{tabular}

Table 2: Components

LAMP's policy involvement followed two broad interrelated phases. In the first phase LAMP established itself as an active participant in the agricultural sector by becoming well acquainted with other donors, government officials and private sector forces who seek to influence agricultural policy. USAID and LAMP identified strategic policy reforms that offer the best opportunity for success and positive impact on the agricultural sector. LAMP also identified individuals who were, or had the capacity to be, change agents capable of mobilizing people and resources. The second phase saw LAMP transition to catalyst and supporter of local participatory efforts.

To truly serve as a forum to build consensus and push the agricultural agenda, local participatory efforts had to include key local stakeholders such as the Agricultural Institutes, the private sector, the Regional Development Agencies, local governments, and the agricultural associations, that could all contribute to the development of the policy environment at the local, entity and national levels. These efforts led to the establishment of formal and informal associations, which LAMP trained and supported in their efforts to lobby government. LAMP's activities in this arena were sometimes challenged by the various political machines. By continually pushing forward the agricultural agenda, and by using resources judiciously, LAMP seemed to have a positive impact on the legislative and regulatory environment.

Table 2 summarizes LAMP's project components designed to overcome the constraints identified.

\section{Results and discussion}

While LAMP's contract placed it in a position of implementer, the success of LAMP's initiatives required attention and action from myriad stakeholders. Thus perhaps LAMP's role was more akin to a facilitator - a bridging organization designed to match stakeholders and create the scaffolding necessary for development to take place.

By interpreting LAMP's actions as complex sets of interorganizational relationships, we reframed theoretically their fundamental raison d'etre. We found ourselves reminded of Porter's cluster concept. The relationships discussed below fit nicely into the overall conception of the agricultural cluster. No single local or international organization could reform agriculture. Many organizations played various roles in this process. However, aid organizations may be particularly well placed to create the interorganizational scaffolding, within which success might be achieved, through conferences, meetings, task forces, study trips, consulting, etc. The LAMP program name actually implied as much, 


\begin{tabular}{|l|c|c|c|c|c|}
\cline { 2 - 5 } \multicolumn{1}{c|}{} & $\begin{array}{c}\text { Institutional } \\
\text { Environment }\end{array}$ & $\begin{array}{c}\text { Market } \\
\text { Linkages }\end{array}$ & $\begin{array}{c}\text { Inefficient } \\
\text { Production }\end{array}$ & $\begin{array}{c}\text { Land } \\
\text { Ownership }\end{array}$ & \\
\hline $\begin{array}{l}\text { Market Chain } \\
\text { Development }\end{array}$ & & $\mathbf{X}$ & & \\
\hline $\begin{array}{l}\text { Strengthening } \\
\text { Market Integrators }\end{array}$ & & $\mathbf{X}$ & $\mathbf{X}$ & \\
\hline Access to Credit & & & & $\mathbf{X}$ \\
\hline $\begin{array}{l}\text { Policy \& Regulatory } \\
\text { Environment }\end{array}$ & $\mathbf{X}$ & & & $\mathbf{X}$ \\
\hline
\end{tabular}

Table 3: Constraints and solutions

overtly; "linking agricultural markets with producers." Below we discuss the constraints and proposed solutions across the three IOR types, summarized in Table 3.

\subsection{Within the International Community}

Many donors provided assistance to the agricultural sector, some providing relief commodities at an earlier stage (IFAD, EU, World Bank, the Netherlands) followed by more development-oriented activities. Others were more recently involved in only development issues. The most significant programs were funded by the USAID, World Bank, IFAD, EU and GTZ. The Dutch, Swiss, Swedes, Norwegians and Japanese also provided assistance. For the most part development professionals sought coordinated approaches to insure effective project results. However, relationships within the international community tended to be fraught with personal, international, political and professional barriers that inhibited coordination.

LAMP coordinated and participated in numerous coordination meetings held throughout the country to insure their work complemented and supported those identified above. The task of coordination was limited to some extent by political and legislative mandates and oversight from home country constituents. However, agricultural issues tended to be rather benign in this respect. More often, professionals reported logistical concerns and timing pressures as greater impediments to coordination. Development professionals are tightly bound to their statements of work and often contracts with donors provide minimal flexibility. As such, even where minor efficiencies could be found, budget restrictions, timelines, currency fluctuations, fiscal years and other pragmatic obstacles inhibited better information sharing and cooperative action.

Regardless, much of LAMP's work revolved around IOR activities, though not explicitly identified in the work plan. For example, when the project work activities began, LAMP contacted as many possible donors and local partners that were active in agricultural sector. They "got a running start" from leads provided by USAID because they had already contacted many of these organizations when they were designing the LAMP project $9-12$ months before ARD began its work activities. One of LAMP's primary goals was not to overlap other projects or duplicate their activities. This was not too difficult since many projects had a smaller geographical focus (i.e. Srebrenica area or the Vlasic plateau area), or the other projects only focused on selective sub-sectors of agriculture (i.e. organic food).

LAMP was instructed by USAID to focus more on commercially-oriented farming, not subsistence farming. Many humanitarian organizations supported return of refugees, which is often subsistence farming. There is a "big gray area" between subsistence vs. commercially oriented farming. If LAMP found clients they could not help, they would be referred to one of the humanitarian organizations. Since it's been 11 years since the end of the war, and $\mathrm{BiH}$ is a very small country, most farmer groups have been in contact with one or more humanitarian organizations.

LAMP also insured that their work built upon USAID's other projects, for example, Business Finance (BF) and Business Consulting (BC) projects. $\mathrm{BF}$ and $\mathrm{BC}$ were more oriented to companies and large food processors, however, they provided good contacts for LAMP. The LAMP staff that once worked with BF provided LAMP with instant credibility. And LAMP used those contacts with food processors to connect them to local cooperatives and growers who supplied raw materials. When USAID decided to help the business community in $\mathrm{BiH}$, they first addressed the needs of the banking sector, business regulations and key companies in the supply chain. Once these elements were somewhat rehabilitated, only then could USAID look at other elements of the supply chain such as agricultural suppliers.

LAMP coordinated activities in each of their four strategic components with other international organizations on an ad hoc basis. At one time, the OHR had an agricultural committee, which consisted of various agricultural assistance donors/projects in the country. LAMP was one of many on this committee. The entity ministries of agriculture also participated on the 
committee. The committee only met a few times. The problem became that "it was a group of agricultural projects sitting around the table telling each other what they do." Most players already knew what each other was doing through informal channels. And many were already coordinating with each other where appropriate. As one professional suggested, "back in '96 - '98 it may have made more sense to form such a committee, but in 2004 it no longer made sense." The committee just stopped meeting, a common coordination problem.

A good example of donor coordination existed between LAMP and Israel's MASHAV agency. Israel did not have a resident Ambassador to $\mathrm{BiH}$, nor any offices in $\mathrm{BiH}$. Israel wanted to help $\mathrm{BiH}$, but representatives were uncertain how to deliver their assistance. They approached LAMP to collaborate with MASHAV to deliver agricultural assistance to BiH. MASHAV offered expert agricultural consultants (greenhouse experts) that were available to work overseas for short term assignments, plus MASHAV offered trainings in Israel.

LAMP offered a great network of local consultants on the ground and could identify willing attendees at trainings offered by MASHAV, either in $\mathrm{BiH}$ or Israel. An arrangement emerged where LAMP organized (with local partners) all the local logistics (rooms, invite the right attendees, vehicles, etc.) and MASHAV sent their consultants. LAMP also identified key local individuals who would be appropriate for MASHAV classes in Israel. It proved to be a very good relationship.

Activities within the international community tended to be dominated by efforts to provide a forum for the exchange of ideas, and a mechanism to identify niches and avoid overlaps. The international organizations saw working together as an effort to increase advocacy, speak in one voice and garner political support for related actions. And at times, they found ways to actually collaborate on specific projects that were mutually beneficial.

\section{2. Between International and Local Organizations}

In general, the International Community's activities were well-received in the local agriculture sector. At times, locals stressed that international consultants were ill-equipped and uninformed about local conditions. Professionals countered that that awareness was hampered by the lack of participation and active local engagement. As projects and professionals remained in country over time, such complaints diminished considerably. For example, LAMP's policy coordinator became very well respected by local agricultural stakeholders. After having been in the country for several years, he developed powerful connections and great insight into the agricultural sector. However, such praise about international advisors proved rare.

The Bulldozer Committee and the geographically focused sub-committees that it formed proved to be successful in mobilizing locals determined to implement change. Unfortunately, the Bulldozer sub-committee for Agriculture and Natural Resources never met. The future success of a Bulldozer subcommittee for agriculture and natural resources could have been the precursor to the formation of successful Competitiveness Council for Agriculture, as some had hoped. But no such organization emerged.

At times some local partners expressed frustration because they equated LAMP assistance with money support (grants) for their activities. Once LAMP rejects a grant request, relationships can tarnish quickly. But the vast majority of LAMP clients understood and appreciated LAMP's purpose, whether a grant was involved or not. In most cases LAMP clients did not receive a grant from the project, instead only receiving technical assistance, consulting and networking.

With respect to working with local agencies and ministers, LAMP officials found it at times difficult and frustrating, depends on the minister and the entity. Two ministers of agriculture in the RS (there have been three since the LAMP project began) came to LAMP for input. The Federation minister did not seek LAMP input, but his deputy did.

The parliaments in $\mathrm{RS}$ and $\mathrm{BiH}$ have special agricultural committees made up of legislators. These agricultural committees are partly designed to act as an oversight body of the entity ministries of agriculture. Some members of these committees came to LAMP seeking input occasionally. LAMP was viewed as USAID's resource to help farmers. The government used LAMP when it helped them achieve their goal, but they did not view LAMP as a "partner." Government agencies were also constrained by the overly burdensome political structure and corrupt, or at least questionable, partisan appointments of individuals from the 'right' party.

The private sector was more eager to work towards solving their problems and introducing new techniques that could make them more competitive. They encouraged the government to institute change that protected their markets or subsidized their production. They also appreciated technical advice. In all, they were perhaps most receptive to LAMP.

With respect to the IOR literature, therefore, relationships between the international community and local governmental agencies seems dominated by the lack of political will, leadership, funding levels, changes in tasks and priorities over time, and the basic organizational concerns of time, skills, and abilities of 
local partners. Relationships between LAMP and private sector firms were much more positive.

\subsection{Among Local Organizations}

A specific problem for the agricultural sector was the lack of cooperation between the Ministries of Agriculture and the Ministries of Health concerning food safety control. There was also insufficient cooperation between the State Ministry of Foreign Trade and Economic Relations and the Ministries at the entity level to institute, for example, a system of product certification to allow exports of certain agricultural products, or explicit regulations to facilitate better livestock monitoring required, for EU market entry of livestock products of livestock products. These are critical reforms that require close, cross-sectoral working relationships between $\mathrm{BiH}$ players.

At the canton level, they are "stuck." The structure simply isn't conducive to collaboration between the entities. However, between ethnic groups of farmers, for example, groups seemed willing to work together. For example, the Dairy Processors Association was formed under LAMP's watch. The Fruits and Vegetables Association grew from eight to 40 members, and there are many local or entity honey associations, and a meeting was organized to establish a $\mathrm{BiH}$ level honey association.

With respect to the IOR literature, relationships among $\mathrm{BiH}$ stakeholders tend to be dominated by competition, but more often by political problems and the lack of an effective government structure or perhaps more importantly, an effective ideology about the role of government and its relationship to the private sector. Thus the regions cannot work together effectively due to the structures put in place after the war. It is not ethnic barriers, as many claim, rather it is the mechanisms designed to minimize those differences that often prove to be the biggest problem.

\section{Conclusions}

LAMP consultants, participants and observers of the sector rarely identified ethnic differences as the cause of failed reforms. This was in sharp contrast to reports in other sectors like media, privatization or refugee return for example where ethnic differences and local obstruction stymied reform efforts (Martin, 2004; Martin and Millesen, 2003). More importantly, market links, training seminars and study tours were frequently attended by all three ethnic groups, without incident. However, such success came largely at the individual and local level. At the institutional level, with respect to the state and the entities, cooperation across lines proved more difficult due to complex regulations, politics and ineffective legislation.

This case highlights the links between levels of analysis in interorganizational studies and development studies. What takes place at one level must be supported and complemented by change at higher or lower levels. Such thinking reflects Porter's cluster competitiveness approach. While specific components of the sector advanced nicely, the cluster as whole remained handicapped. All components must move together.

LAMP served as a lynchpin organization charged with supporting the entire cluster through their interorganizational matchmaking. LAMP clearly did not act in a vacuum. LAMP recognized the two way flow of information so vital to the success of their work. More importantly, USAID also recognized this. Needs and priorities early in the project were supported and addressed, revealing additional, more nuanced needs and priorities for a later date. AID responded to the concerns and redirected programmatic activity accordingly.

This project helped us think in a very overt way, about redefining the work of LAMP, or any development organization, away from its specific contractual obligations to AID or any donor, towards a more nuanced understanding of the importance of interorganizational relationships as the means, or process for achieving success. AID would do well to more explicitly require expertise in such areas among all contractors, recognizing that accomplishing tasks is perhaps of less importance than creating lasting, sustainable relationships among local players who will ultimately work together to solve those tasks. It is the reincarnation of the old adage of providing fish or teaching to fish.

But we must be sensitive to USAID's and other development organizations' missions. In the early years after a conflict, at times, the task itself is dominant. At a more mature stage, a decade after the end of conflict, for example, aid organizations should be more concerned with sustainable processes than outcomes to some degree. LAMP, it seems, realized that only by seeking input, engagement and ownership from all stakeholders, could they succeed in their desired and contracted goals.

In summary, IORs served as the critical mechanism for seeking and securing such broad stakeholder support and sustainability. Our conceptualization of development assistance as a complex system of IORs seemed appropriate. From an IOR analytical perspective, we reframe the constraints and opportunities highlighted in the LAMP work plan as follows.

At the environmental level, interorganizational dynamics were moderated and mediated by the $\mathrm{BiH}$ political arena, as well as the macro social, economic and political changes in the country over time. In addition, Bosnia and Herzegovina's position in the global limelight 
for development waned over time. As a result, funding and attention dropped dramatically. At the population level, the International Community describes a unique interorganizational network of action. While on occasion the IC works well together and speaks with one voice, at other times it exhibits sharp infighting. These dynamics are critical to understanding development. Dynamics among and between local players prove equally influential in program success. At the organizational level, we must consider that effective relationships take time, resources and people skilled in brokering a cooperative culture that fosters coordinated action among all stakeholders. Many organizations simply do not have such capacity given staffing and contractual obligations and limitations. At the group level, the importance of personal networks and dynamics within task forces prove important. Individual roles within groups do not always align with organizational positions. And finally, at the individual level, some good leaders have emerged, but ambition, personal agendas and politics play crucial roles that limit successes as much as they advance them.

With respect to development assistance, we return to the notion of dependency. Dependency represents an extreme form of partnership where the power balance is heavily tilted toward the international community. However, creating partnerships, regardless of imbalances, is a first step toward more effective long-term working relationships. The power balance, however, must be respected and monitored as it changes over time, as the country in question, in this case Bosnia and Herzegovina, matures, changes and develops. The overt recognition of the importance of multiple stakeholders and the need to bring them to the table helps create linkages that foster development. The international community serves as matchmaker or broker in this process. To do so effectively facilitates the move toward local ownership of reform so critical to ultimate success.

The paradox of development assistance lies in the difficult practice of determining when that actually can or will take place. When must the donor and implementing organizations relinquish their control and power in favor of less optimal but locally owned reform efforts? We believe our IOR approach helps reconceptualize development assistance and might lead to answers to questions such as these that plague development efforts both theoretically and practically. .

\section{References}

Aubrey, L. 1997. The politics of development cooperation: NGOs, gender and partnerships in Kenya. NY: Routledge.

Barr, P.S. 1998. Adapting to unfamiliar environmental events: A look at the evolution of Interpretation and its role in strategic change. Organization Science 9(6): 644-669.
Benson, J.K. 1975. The interorganizational network as a political economy. Administrative Science Quarterly 20: 229-249.

Black, J.K. 1999. Development in Theory and Practice. Oxford: Westview Press.

Boyce, J.K. 1995. Adjustment toward peace: an introduction. World Development 23(12): 2067-2077.

Brinkerhoff, D.W. 1996. Coordination issues in policy implementation networks: An illustration from Madagascar's environmental action plan. World Development 24(9): 1497-1510.

Brinkerhoff, D.W. 2004. Good governance, clientelism, and old patrimonialism: New perspectives on old problems. International Public Management Journal 7(2): 163-184.

Brinkerhoff, J.M. 2004. Emerging trends in development management: Tension and complexity in the continuing search for solutions. International Public Management Journal 7(2): 149-161.

Burns, L.R. and Wholey, D.R. 1993. Adoption and abandonment of matrix management programs: Effects of organizational characteristics and interorganizational networks. Academy of Management Journal 36(1): 106-138.

Carrol, G.R. and Teo, A.C. 1996. On the social networks of managers. Academy of Management Journal 39(2): 421-440.

Clark, B.R. 1965. Interorganizational patterns in education. Administrative Science Quarterly 10: 224-237.

Dickson, P., and Weaver, K. 1997. Environmental determinants and individual-level moderators of alliance use. Academy of Management Journal 40: 404-425.

Emery, F.E. and Trist, L. 1965. Causal texture of organizational environments. Human Relations 18: 18-32.

Evans, P. 1996a. Introduction: Development strategies across the publicprivate divide. World Development 24(6): 1033-1037.

Evans, P. 1996b. Government action, social capital and development: Reviewing the evidence on synergy. World Development 24(6): 11191132.

Evans, W.M. and Klemm, R.C. 1980. Interorganizational relations among hospitals: A strategy, structure, and performance model. Human Resources 33(5): 315-337.

Fombrun, C.J. 1986. Structural dynamics within and between organizations. Administrative Science Quarterly 31: 403-421.

Ghoshal, S. and Bartlett, C.A. 1990. The multinational corporation as an interorganizational network. Academy of Management Review 15(4): 603-625.

Goldsmith, A.A. (1996). Strategic thinking in international development: Using management tools to see the big picture. World Development 24(9): 1431-1439.

Granovetter, M. 1973. The strength of weak ties. American Journal of Sociology 78(6): 1360-1380.

Gray, B. 1985. Conditions facilitating interorganizational collaboration. Human Relations 38(10): 911-936.

Griffen, K. 2000. Studies in development strategy and systematic transformation. NY: St. Martin's Press.

Gulati, R. 1995a. Does familiarity breed trust? The implications of repeated ties for contractual choices in alliances. Academy of Management Journal 38: 85-112. 
Gulati, R. 1995b. Social structure and alliance formation patterns: A longitudinal analysis. Administrative Science Quarterly 40: 619-653.

Gulati, R and Gargiulo, M. 1999. Where do interorganizational networks come from? American Journal of Sociology 104(5): 1439-1493.

Gulati, R. and Westphal, J.D. 1999. Cooperative or controlling? The effects of CEO-board relations and the content of interlocks on the formation of joint ventures.

Administrative Science Quarterly 44: 473-506.

Hannan, W.F. and Freeman, J.T. 1977. The population ecology of organizations. American Journal of Sociology 82: 131-160.

Hardy, C. and Philips, N. 1998. Strategies of engagement: Lessons from the critical examination of collaboration and conflict in an interorganizational domain. Organization Science 9(2): 217-230.

Hasic, T. 2006. Management of Complexities in Post-war Reconstruction (BiH and the International Community. SEE Journal. February: 6-17.

Haughton, J. 1998. The reconstruction of war-torn economies. CAER Discussion Paper No. 23. Cambridge: Harvard Institute for International Development.

Human, S.E. and Provan, K.G. 2000. Legitimacy building in the evolution of small-firm multilateral networks: A comparative study of success and demise.Administrative Science Quarterly 45: 327-365.

Ibarra, H. 1993a. Network centrality, power, and innovation involvement: Determinants of technical and administrative roles. Academy of Management Journal 36(3): 471-501.

Ibarra, H. 1993b. Personal networks of women and minorities in management: A conceptual framework. Academy of Management Review 18(1): 56-87.

Inkpen, A.C. and Beamish, P.W. 1997. Knowledge, bargaining power and the instability of international joint ventures. Academy of Management Review 22(1): 177-202.

Kiggundu, M.N. 1996. Integrating strategic management tasks into implementing agencies: From firefighting to prevention. World Development 24(9): 1417-1430.

Klonglan, G.E., Warren, R.D., Winkelpleck, J.M., and Paulson, S.K. 1976.

Interorganizational measurement in the social services sector: Differences by hierarchical level. Administrative Science Quarterly 21: 675-687.

Kochan, T.A. 1975. Determinants of the power of boundary units in an interorganizational bargaining relation. Administrative Science Quarterly 20: 434-451.

Koza, M.P. and Lewin, A.Y. 1998. The co-evolution of strategic alliances. Organization Science 9(3): 255-263

Kraatz, M.S. 1998. Learning by association? Interorganizational networks and adaptation to environmental change. Academy of Management Journal 41(6): 621-643.

Lammers, C.J. 1988. The interorganizational control of an occupied country. Administrative Science Quarterly 33: 438-457.

Larson, A. 1992. Network dyads in entrepreneurial settings: A study of the governance of exchange relationships. Administrative Science Quarterly 37: 76-104.

Larsson, R. and Finkelstein, S. (1999) 'Integrating strategic, organizational, and human resource perspectives on mergers and acquisitions: A case study of synergy realization'. Organizational Science 10(1): 1-25.
Lawrence, P.R. and Lorsch, J.W. 1967. Organization and environment. Cambridge: Harvard University Press.

Leeson, P.F. and Minogue, M.M. 1988. Perspectives on development. Manchester: Manchester University Press.

Levine, S. and White, P.E. 1961. Exchange as a conceptual framework for the study of interorganizational relationships. Administrative Science Quarterly 5: 583-601.

Martin, E. 2004. Privatization in Bosnia and the Craft of IOR Process Analysis. Organization Studies 25(7): 1115-1157.

Martin, E. and Miller, J. 2003. Developing Bosnia and Herzegovina: Understanding Large-Scale Interorganizational Systems. Voluntas 14(2): 145-166.

McCaffrey, D., Faerman, S., And Hart, D. 1995. The Appeal and Difficulties of Participative Systems. Organization Science 6: 603-627.

Meyer, A. D. 1982. Adapting to environmental jolts. Administrative Science Quarterly 27:515-537.

Miner, A.S., Amburgey, T.L. and Stearns, T.M. 1990. Interorganizational linkages and population dynamics: Buffering and transformational shields. Administrative Science Quarterly 35: 689-713.

Molnar, J.J. 1978. Comparative organizational properties and interorganizational interdependence. Social Science Review 63(1): 2447.

Mosse, D., Farrington, J. and Rew, A. 1998. Development as Process. ODI Development Policy Studies. NY: Routledge Research.

Njoh, A.J. 1993. The effectiveness theory of interorganizational relations explored in the context of a developing nation. International Review of Administrative Science 59: 235-250.

Ostrom, E. 1996. Crossing the great divide: Coproduction, synergy and development. World Development 24(6): 1073-1087.

Parkhe, A. 1993. Strategic alliance structuring: A game theoretic and transaction cost examination of interfirm cooperation. Academy of Management Journal 36: 794-829.

Pech, L. (2000) 'Is Dayton Falling?: Reforming Media in Bosnia and Herzegovina, International Journal of Communications Law and Policy, Issue 4, Winter, pp. 1-28.

Porter, M.E. (2002). Global Competitiveness Report, World Economic Forum

Powell, W., Koput, K.W., and Smith-Doerr, L. 1996. Interorganizational collaboration and the locus of innovation: Networks of learning in biotechnology. Administrative Science Quarterly 41: 116-145.

Provan, K.G. and Milward, H.B. 1995. A preliminary theory of interorganizational effectiveness: A comparative study of four community mental health systems. Administrative Science Quarterly 40: 1-33.

Putnam, R.D. 2000. Bowling alone: The collapse and revival of American community. NY: Simon and Schuster.

Randall, V. and Theobald, R. 1998. Political change and underdevelopment. Durham: Duke University Press.

Rice, R.E. and Aydin, C. 1991. Attitudes toward new organizational technology: Network proximity as a mechanism for social information processing. Administrative Science Quarterly 36: 219-244.

Riggs, F. 1960. Comparative Administration Group. Ford Foundation.

Rondinelli, D. 1994. Strategic management in foreign aid agencies: Developing a results-based performance system. International Review of Administrative Sciences 60: 465-482. 
Rondinelli, D. 1987. Development administration and US foreign policy. Boulder: Lynne Renner.

Ruef, M. and Scott, W.R. 1998. A multidimensional model of organizational legitimacy: Hospital survival in changing institutional environments. Administrative Science Quarterly 43: 877904.

Schermerhorn, J.R. 1975. Determinants of interorganizational cooperation. Academy of Management Journal 18(4): 846-856.

Shenkar, O. and Li, J. 1999. Knowledge search in international cooperative ventures. Organization Science 10(2): 134-143.

Shuey, A. (2003) 'Democracy According to Dayton: The United States and International Community's Role in Bosnia-Hercegovina, International Affairs Review, pp. 110-118.

Sklar, R.L. 1987. Developmental democracy. Society for Comparative Study of Society and History. 686-714.

Sklar, R.L. 1995. The new modernization. Issue: A Journal of Opinion 23(1): 19-21.

Spradley, J.P. (1979) The ethnographic interview. Harcourt Brace, Fort Worth.

Strauss, A. and Corbin, J. (1990) Basics of Qualitative Research. Sage Publications, CA.

Svensson, J. 1997. When is foreign aid policy credible? Aid dependence and conditionality. The World Bank, Policy Research Department Policy Research Working Paper \#1740, Washington, DC.

Terreberry, S. 1968. The evolution of organizational environments. Administrative Science Quarterly 12: 590-613.

Tichy, N.M., Tushman, M.L. and Fombrun, C. 1979. Social network analysis for organizations. Academy of Management Review 4(4): 507-519.

Tisch, S.J. and Wallace, M.B. 1994. Dilemmas of development assistance: The what, why and who of foreign aid. Boulder: Westview Press.

Todaro, M. 1994. Economic development in the third world, $5^{\text {th }}$ ed. London: Longman.

Van de Ven, A. H. 1976. On the nature, formation and maintenance of relations among organizations. Academy of Management Review 1(4): 24-36.

Weber, J. 1995. Influences upon organizational ethical subclimates: A multi-departmental analysis of a single firm. Organization Science 6(5): 509-523.

Westphal, J.D., Gulati, R. and Shortell, S.M. 1997. Customization or conformity? An institutional and network perspective on the content and consequences of TQM

adoption. Administrative Science Quarterly 42:366-394.

Young-Ybarra, C. and Wiersema, M. 1999. Strategic flexibility in information technology alliances: The influence of transaction cost economics and social exchange theories. Organization Science 10(4): 439-459.

Zaheer, A., McEvily, B. and Perrone, V. 1998. Does trust matter? Exploring the effects of interorganizational and interpersonal trust on performance. Organization Science 9(2): 141-159. 